\title{
Electrochemical Reduction of Isatin-monohydrazone on Mercury Electrode
}

\author{
Semiha Çakır, ${ }^{\text {a,* }}$ Ender Biçer, ${ }^{\mathrm{b}}$ and Emine Yılmaz Arslan ${ }^{\mathrm{a}}$ \\ ${ }^{a}$ Department of Chemistry, Faculty of Science, Gazi University, 06500 Teknikokullar - Ankara, Turkey \\ ${ }^{\mathrm{b}}$ Department of Chemistry, Faculty of Arts and Science, Ondokuz Mayı University, 55139, Atakum-Samsun, Turkey
}

RECEIVED AUGUST 22, 2014; REVISED JANUARY 8, 2015; ACCEPTED JANUARY 16, 2015

\begin{abstract}
Electrochemical behaviour of isatin monohydrazone (IM) on a hanging mercury drop electrode in the Britton-Robinson (B-R) buffer solution of $\mathrm{pH}=2.00-9.00$ has been investigated using square-wave voltammetry (SWV) and cyclic voltammetry $(\mathrm{CV})$ techniques. In the $\mathrm{pH}$ range of $2.00-5.00$, the voltammogram of IM exhibited a single cathodic irreversible peak. When the $\mathrm{pH}$ value exceeds 5.00, a new cathodic irreversible peak was also seen. According to the voltammetric data, a plausible electrode reaction mechanism of IM was proposed. The first reduction peak of IM is resulted from the reduction of $=\mathrm{N}-\mathrm{NH}-$ group with consumption of $2 \mathrm{e}^{-} / 2 \mathrm{H}^{+}$. Also, its second cathodic peak is formed by the participation of $2 \mathrm{e}^{-} / 2 \mathrm{H}^{+}$for the reduction of $-\mathrm{N}=\mathrm{N}-$ group on its tautomeric form.
\end{abstract}

Keywords: isatin monohydrazone, voltammetry, electrode mechanism, tautomerism, ionization

\section{INTRODUCTION}

The chemistry of isatin (indole-2,3-dione) and its derivatives is particularly interesting owing to their wide application for analytical and synthetic purposes. It has important biological activities such as anti-inflammatory, antibacterial, anticonvulsant and antioxidant properties. ${ }^{1,2}$ Many new compounds of isatin were synthesized and reported for antibacterial, ${ }^{3}$ antifungal, ${ }^{4}$ anti-HIV ${ }^{5}$ and anticonvulsant. ${ }^{6,7}$ The monohydrazone ${ }^{8}$ and bishydrazone compounds ${ }^{9}$ from isatin have been prepared and widely used in medicine. For example, isatin hydrazone was used as a detecting reagent for 3-ketosteroids. ${ }^{10}$ Hydrazones and their metal complexes attracted much attention because of their medicinal, physicochemical properties and applications in many important chemical processes. ${ }^{11-14}$

The electrochemical behaviors of isatin and some of its derivatives ${ }^{9,15-21}$ were examined. The knowledge of the redox properties of hydrazone compounds is important for a better understanding of their behaviors in both chemical and biological processes. Electrochemical methods are very favorable to obtain this information and successfully used to the redox behavior of various biological compounds. ${ }^{22-29}$ The hydrazones are electroactive compounds. In the literature, there are many published works on the electrochemical reduction of azo and hydrazone compounds. ${ }^{30-39}$ Isatin-3-hydra- zone (IM) was detected during the electroreduction of 3-diazo-oxindole at $\mathrm{pH}>8.5 .^{40,41} \mathrm{In}$ a recent paper, the redox behavior of isatin-3-hydrazone at a glassy carbon electrode has been studied by Olivera et al. ${ }^{21}$ Nevertheless, the comprehensive research of the electrochemical behavior of IM on the hanging mercury drop electrode (HMDE) will be also useful in the clarification of the electron transfer pathways of biological reactions of the hydrazones which possess some pharmaceutical activities. ${ }^{42}$

In the present research, the redox properties of IM on the mercury electrode in different $\mathrm{pH}$ media have been examined by using square-wave and cyclic voltammetry techniques. This study has reported the results together with a discussion of the electrode reaction mechanism of IM.

\section{EXPERIMENTAL}

\section{Materials and Reagents}

Isatin and hydrazine hydrate (reagent grade $98.0 \%$ ) were obtained from Sigma-Aldrich. Methanol was of analytical grade and purchased from Merck. All solutions were prepared using triple distilled and deinonized water. B-R buffers were made from boric acid, acetic acid, and phosphoric acid, all $0.04 \mathrm{M}$, and titrated to the desired value with $0.2 \mathrm{M} \mathrm{NaOH}$. B-R buffers were

\footnotetext{
* Author to whom correspondence should be addressed. (E-mail: scakir@gazi.edu.tr)
} 
prepared using analytical grade reagents (Merck or Sigma) and were used as supporting electrolyte.

\section{Apparatus}

An EG\&G PARC Model 303A HMDE three electrode system (mercury working electrode, platinum counter electrode and $\mathrm{Ag}|\mathrm{AgCl}| \mathrm{KCl}_{\text {sat. }}$ reference electrode) along with EG\&G PAR 394B polarographic analyzer used for voltammetric measurements at room temperature.

\section{Method}

Before each measurement, the solutions were deaerated by a stream of pure nitrogen. A known volume of $1 \times 10^{-3}$ M IM solution was added to the electrochemical cell, which was closed, deaerated, and blanketed with oxygen-free nitrogen. Then, the voltammograms were recorded. The square-wave voltammograms were obtained using the following experimental parameters: pulse height, $20 \mathrm{mV}$; scan increment, $2 \mathrm{mV}$; frequency, $50 \mathrm{~Hz}$; scan rate, $100 \mathrm{mVs}^{-1}$; drop size medium and equilibrium time $5 \mathrm{~s}$. Cyclic voltammograms were obtained for drop size medium and equilibrium time $5 \mathrm{~s}$ in the range of scan rate of $200-1000 \mathrm{mVs}^{-1}$. Each measurement was carried out on a fresh mercury drop.

\section{General Procedure for Synthesis of IM}

According to the procedure, reported by Murukan and Mohanan, ${ }^{43}$ IM was prepared by refluxing together equimolar solutions of isatin and hydrazine hydrate in methanol for $3 \mathrm{~h}$ (Scheme 1). On cooling, the monohydrazone crystallized from the reaction mixture. Recrystallization from methanol afforded beautiful yellow crystals of the monohydrazone, m.p. $226^{\circ} \mathrm{C}$. The melting point of IM is different from those of isatin (m.p. = $\left.203^{\circ} \mathrm{C}\right)^{44}$ and hydrazine hydrate (m.p. $\left.=-51^{\circ} \mathrm{C}\right) .{ }^{45}$ The m.p. of IM is almost same with that $\left(225^{\circ} \mathrm{C}\right)$ of the synthesized by Kulkarni et al. ${ }^{46}$<smiles>O=C1Nc2ccccc2C1=O</smiles>

isatin

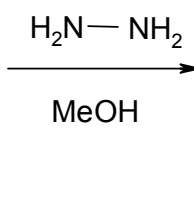<smiles>N/N=C1\C(=O)Nc2ccccc21</smiles>

IM
Scheme 1. The synthesis of IM

\section{RESULTS AND DISCUSSION}

\section{Effect of pH}

The electrochemical behavior of IM was studied by using SWV and CV techniques in B-R buffer solutions
$(\mathrm{pH}=2.00-9.00)$. For the $\mathrm{pH}$ range of $2-5$, the squarewave voltammogram of IM exhibited one well-defined reduction peak (peak I) in the potential range of 0.0 to $-1.2 \mathrm{~V}$ vs. $\mathrm{Ag}|\mathrm{AgCl}| \mathrm{KCl}_{\text {sat. }}$ (Figure 1). When the $\mathrm{pH}$ value exceeded 5.0, a new reduction peak (peak II) was observed (Figure 1). In addition, the reduction potential of peak II is more negative than that of peak I. The peak II appears clearly only at at $\mathrm{pH}$ range of 6.00-8.00 (Figure 1) for high IM concentrations ( $\geq 1 \times 10^{-5} \mathrm{M}$ ). This peak (peak II) was not observed at glassy carbon electrode by Olivera et al. ${ }^{21}$ In the literature, ${ }^{47}$ it was reported that the multiplicity waves of various hydrazone derivatives were ascribed to equilibrium among hydrazone, azo, and ene-hydrazine forms. Therefore, these peaks on the voltammograms of IM can be sourced from the ketohydrazo and enol-azo tautomeric forms of IM (Scheme 2). Especially, the appearance of new peak may be attributed to the reduction of the enol-azo form.

Keto-enol tautomerism is catalyzed by either acid or base. Usually the enol is the minority tautomer, but it is more reactive. ${ }^{48}$ In the keto-enol isomerism, the keto form is predominant in an acidic medium and the enol form in an alkaline medium. ${ }^{49-51}$

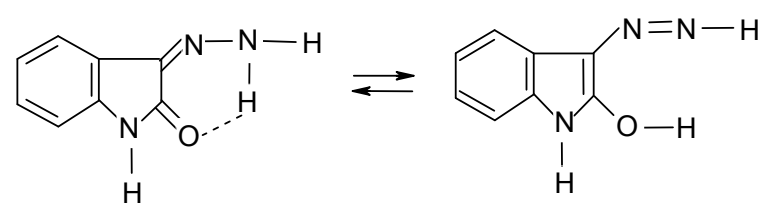

Scheme 2. Keto-hydrazo and enol-azo tautomeric forms exhibited by IM

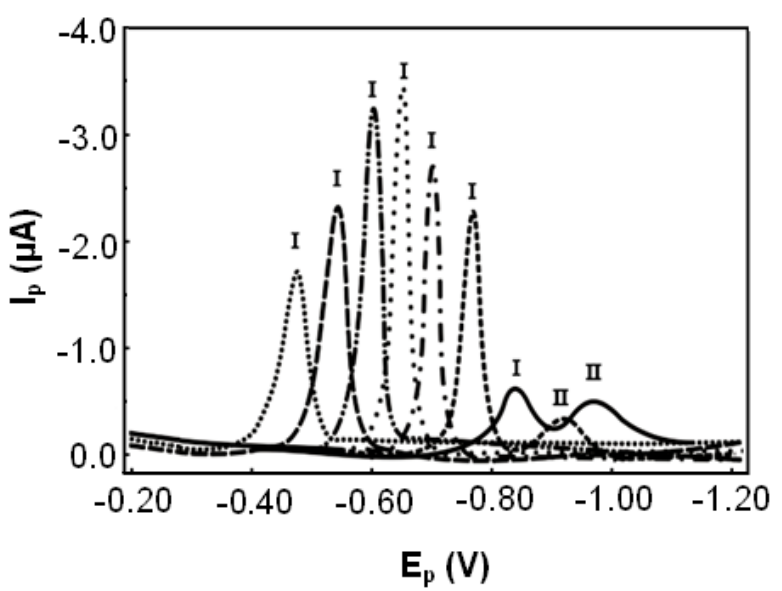

Figure 1. Typical square-wave voltammograms of $1 \times 10^{-5} \mathrm{M}$ IM in B-R buffer at $\mathrm{pH}$ range 2-8. Experimental conditions: pulse height, $20 \mathrm{mV}$; scan increment, $2 \mathrm{mV}$; equilibrium time, $5 \mathrm{~s}$; frequency, $50 \mathrm{~Hz}$; working electrode, $H M D E$, drop size, medium. $\mathrm{pH}=2$ (........); $\mathrm{pH}=3$ (---); $\mathrm{pH}=4$ ( -..-); $\mathrm{pH}=$ $5(. \cdots) ; \mathrm{pH}=6(-\cdot-) ; \mathrm{pH}=7$ (.....); $\mathrm{pH}=8$ (—). 


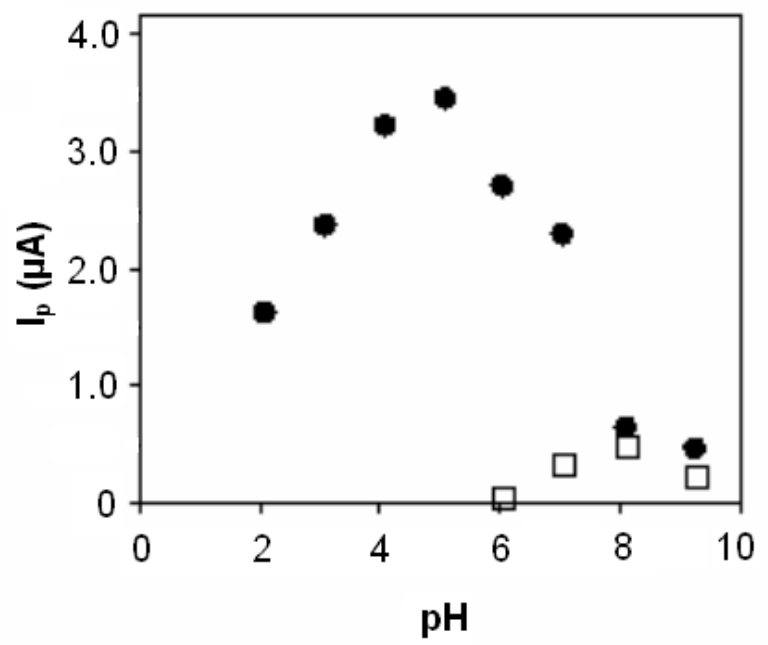

Figure 2. Dependence of peak currents on $\mathrm{pH}$ for $1 \times 10^{-5} \mathrm{M}$ IM in B-R buffer. (-)): peak I; $(-)$ : peak II. Experimental conditions: Square-wave voltammetry; pulse height, $20 \mathrm{mV}$; scan increment, $2 \mathrm{mV}$; equilibrium time, $5 \mathrm{~s}$; frequency, 50 $\mathrm{Hz}$; working electrode, $H M D E$, drop size, medium.

In the range $2 \leq \mathrm{pH} \leq 5$, the current of peak I considerably increased with increasing $\mathrm{pH}$ and then reached a maximum value, which confirms that IM is more electrochemically active at $\mathrm{pH}=5$. The azo tautomeric form of IM may be present in solution but in very small quantities that does not exhibit a voltammetric signal in the $\mathrm{pH}$ range of $2-5$. However, in the range $6 \leq \mathrm{pH} \leq 9$, the current of peak II continues to increase up to $\mathrm{pH}=8$ whereas that of peak I decreases with increasing $\mathrm{pH}$ (Figure 2). Increase in the alkalinity of the medium leads to a shift in the equilibrium towards to the enolazo form. ${ }^{52}$ So, in the range $6 \leq \mathrm{pH} \leq 9$, the appearance of the peak II may be caused from the reduction of the azo tautomeric form of IM, present in effective amount under these conditions. Moreover, the potentials $\left(E_{\mathrm{p}}\right)$ of both reduction peaks (I and II) shifted to more negative values with increasing $\mathrm{pH}$ of the electrolyte (Figure 3 ), indicating that hydrogen ions are involved in the reduction process. The hydrogen ion concentration decreases

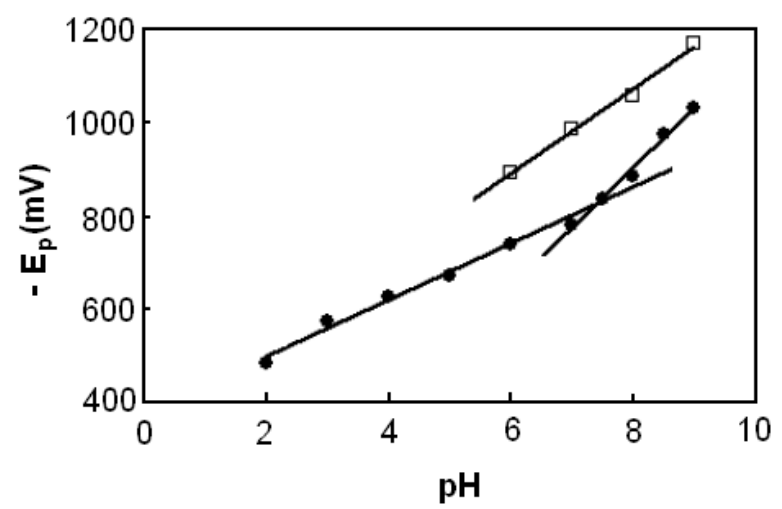

Figure 3. Dependence of the potentials of peak I $(-\bullet)$ and peak II ( $\square-)$ on $\mathrm{pH}$ for $1 \times 10^{-5} \mathrm{M} \mathrm{IM}$. by increasing $\mathrm{pH}$. In this case, the required energy for the reduction of IM increases. Therefore, the peak potentials of IM shifted towards to more cathodic values.

For the peak I, the graph of $E_{\mathrm{p}} v s$. pH exhibits two linear relationships in the $\mathrm{pH}$ range 2.00-9.00. These two linear parts graphically break at $\mathrm{pH}=7.41$ (Figure 3). This $\mathrm{pH}$ value may be attributed to a $\mathrm{p} K_{\mathrm{a}}$, corresponding to the deprotonation of enolic form of IM (Scheme 3). The determined $\mathrm{p} K_{\mathrm{a}}$ value (7.41) of IM in the present study is different from the value $(\sim 9)$ reported by Olivera et $a l .{ }^{21}$ This case might arise from the difference in the experimental conditions (e.g., temperature, ionic strength and the solvent dielectric constant). Because it is well known that $\mathrm{p} K_{\mathrm{a}}$ depends on the experimental conditions. ${ }^{53}$<smiles>[CH-]CNN=C1C(=O)Nc2ccccc21</smiles>

Scheme 3. The ionization of IM

In addition, the potential of peak II is also dependent on $\mathrm{pH}$ (Figure 3). By the effect of $\mathrm{pH}$, in the range 7 $\leq \mathrm{pH} \leq 9$, the magnitude of shift in the potential of first peak (I) is greater than that of the shift of new peak (II) (Figure 3). So, the new peak II overlaps with the first peak I to produce a shoulder peak at $\mathrm{pH}=9$ (Figure 4).

Examination of cyclic voltammograms obtained in the $\mathrm{pH}$ range $2.00-9.00$ reveals that no anodic counter parts of the peaks I and II are seen on the reverse sweep (Figure 5). This result indicated that the electrode process of IM is irreversible under the experimental conditions examined in this study. However, cathodic peak II is only observed at $\mathrm{pH}$ values higher than 5 (Figure 5). As can be seen from Figure 5, the peak II is slightly observed at $\mathrm{pH}=6$. Consequently, cyclic voltammetric results of IM are nearly in agreement with those

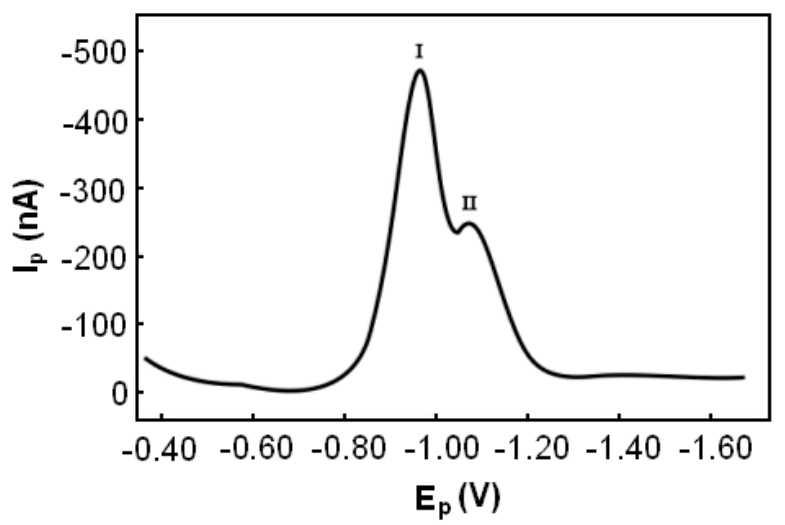

Figure 4. Square-wave voltammograms of $1 \times 10^{-5} \mathrm{M}$ IM in $\mathrm{B}-\mathrm{R}$ buffer at $\mathrm{pH}=9$. (Experimental conditions: pulse height, $20 \mathrm{mV}$; scan increment, $2 \mathrm{mV}$; equilibrium time, $5 \mathrm{~s}$; frequency, $50 \mathrm{~Hz}$; working electrode, $H M D E$, drop size, medium). 

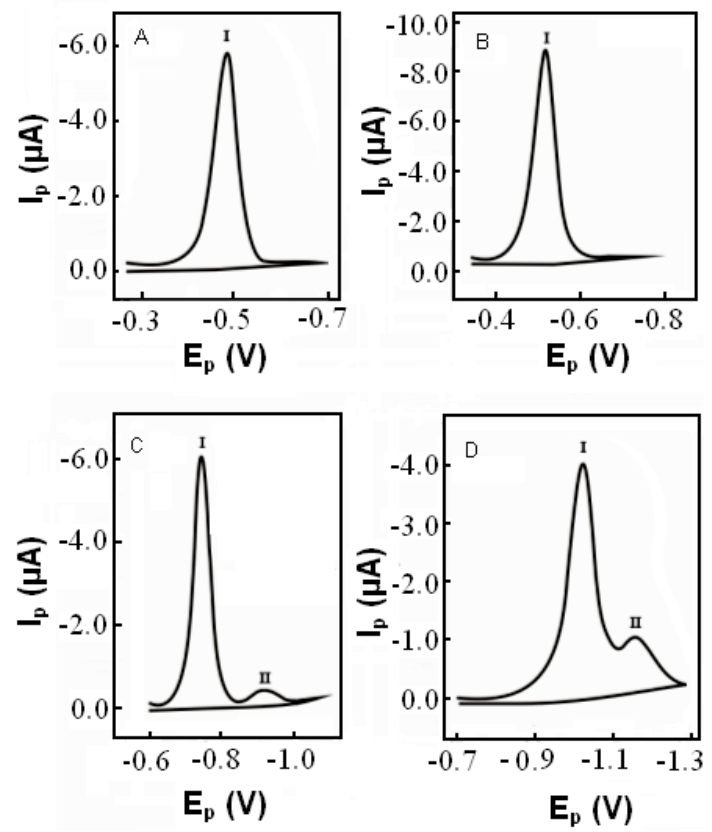

Figure 5. Cyclic voltammograms of $1 \times 10^{-4} \mathrm{M}$ IM in the B-R buffer at $\mathrm{pH}$ range 2-9. $\mathrm{pH}=2(\mathrm{~A}) ; \mathrm{pH}=4(\mathrm{~B}) ; \mathrm{pH}=6(\mathrm{C})$; $\mathrm{pH}=9$ (D). Experimental conditions: scan rate: $200 \mathrm{mVs}^{-1}$, equilibrium time, $5 \mathrm{~s}$; working electrode, $H M D E$, drop size, medium.

obtained by square-wave voltammetry technique on the formation and characteristic values (cathodic currents, peak potentials, etc.) of the peaks I and II.

\section{Effect of the Scan Rate}

The influence of the scan rate $(v)$ on the peak currents $\left(I_{\mathrm{p}}\right)$ of IM was investigated by cyclic voltammetry. The peak current changes linearly with scan rate according to the equation $I_{\mathrm{p}}=A v^{x} .{ }^{54}$ The $x$ values 1.0 and 0.5 are expected for adsorption-controlled and diffusion-controlled reactions, respectively. ${ }^{55,56}$ For cathodic peaks I and II, the linear relationships between $\log I_{\mathrm{p}}$ and $\log v$ are observed at different $\mathrm{pH}$ values (Figure 6). The experimental results are listed in Table 1. As can be seen in Table 1, the slope values of peaks I and II at $\mathrm{pH}=6.0$ are very
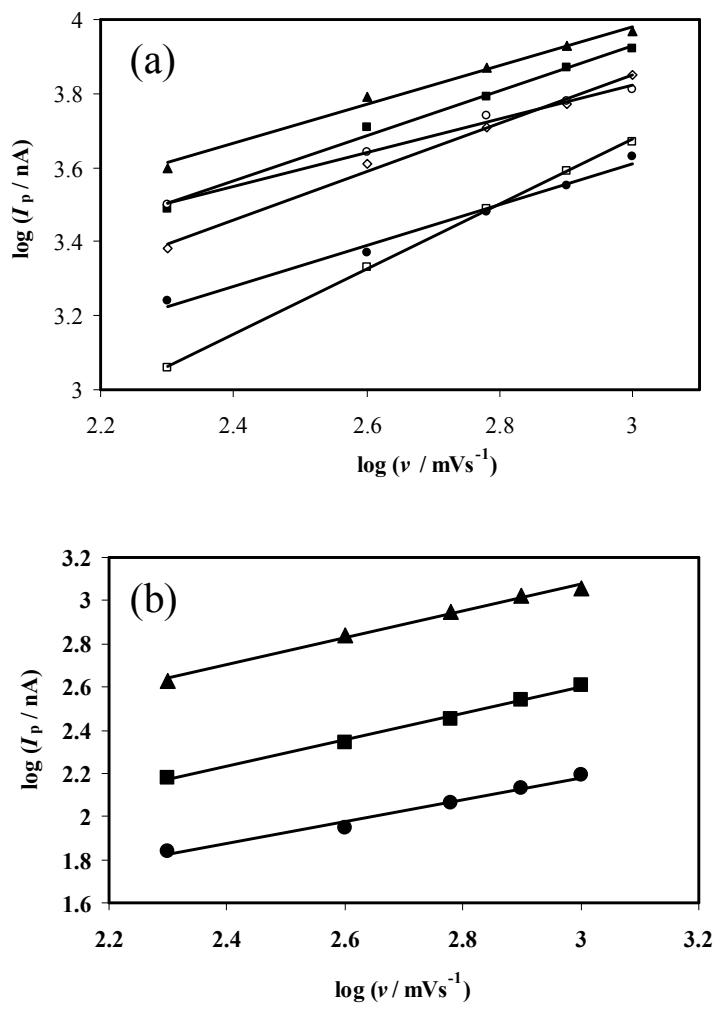

Figure 6. The plots of $\log I_{\mathrm{p}} v \mathrm{~s} . \log v$ for the first reduction peak I (a): at $\mathrm{pH}=2(\diamond) ; \mathrm{pH}=3(\mathbf{\bullet}) ; \mathrm{pH}=5(\mathbf{\Delta}) ; \mathrm{pH}=6(\circ)$; $\mathrm{pH}=8(\bullet) ; \mathrm{pH}=9$ ( $\square)$ and second reduction peak II (b): at $\mathrm{pH}=6(\bullet) ; \mathrm{pH}=8(\mathbf{\bullet}) ; \mathrm{pH}=9(\boldsymbol{\Delta})$ of $1 \times 10^{-4} \mathrm{M} \mathrm{IM}$.

close to the theoretically expected value of 0.5 for a purely diffusion-controlled current. At more acidic or basic solutions, the slope values are bigger than 0.5 . This result indicates that the electrode process of IM is a diffusion-controlled mass transfer, involving a slightly contribution of adsorption.

The half-peak-width, $W_{1 / 2}$ (expressed in V), at the peak half height can be used to calculate $\alpha n$ at each $\mathrm{pH}$ value: ${ }^{57-59}$

$$
W_{1 / 2}=3.52 R T / \alpha n F
$$

Table 1. The cyclic voltammetric data from plots of $\log I_{\mathrm{p}}$ vs. $\log v$ for the first reduction peak (I) and the second reduction peak (II) of $1 \times 10^{-4} \mathrm{M}$ IM at $\mathrm{pH}$ values of $2,3,5,6,8$ and 9 (for the scan rate range: $200-1000 \mathrm{mVs}^{-1}$ )

\begin{tabular}{ccccc}
\hline $\mathrm{pH}$ & Equation for first peak (I) & $\begin{array}{c}\text { Regression } \\
\text { coefficient }\left(r^{2}\right)\end{array}$ & Equation for second peak (II) & $\begin{array}{c}\text { Regression } \\
\text { coefficient }\left(r^{2}\right)\end{array}$ \\
\hline 2 & $\log I_{\mathrm{p}}=0.654 \log v+1.887$ & 0.994 & not observed & not observed \\
3 & $\log I_{\mathrm{p}}=0.609 \log v+2.103$ & 0.992 & not observed & 0.986 \\
5 & $\log I_{\mathrm{p}}=0.528 \log v+2.398$ & 0.992 & $\log I_{\mathrm{p}}=0.505 \log v+0.662$ & 0.995 \\
6 & $\log I_{\mathrm{p}}=0.454 \log v+2.460$ & 0.992 & $\log I_{\mathrm{p}}=0.613 \log v+0.759$ & 0.994 \\
8 & $\log I_{\mathrm{p}}=0.551 \log v+1.958$ & 0.988 & $\log I_{\mathrm{p}}=0.623 \log v+1.209$ & \\
9 & $\log I_{\mathrm{p}}=0.875 \log v+1.052$ & 0.999 & & \\
\hline
\end{tabular}


<smiles>C/N=N/c1c(O)[nH]c2ccccc12</smiles><smiles>[H][Y7]([H])([H])Nc1c(O[2H])[nH]c2ccccc12</smiles>

Scheme 5. Tentative reduction mechanism for peak II (in the $\mathrm{pH}$ range 6-9).

where $F$ is the Faraday constant $\left(96485 \mathrm{C} \mathrm{mol}^{-1}\right), R$ is the standard gas constant $\left(8.314 \mathrm{~J} \mathrm{~mol}^{-1} \mathrm{~K}^{-1}\right)$, and $T$ is the temperature (expressed in $\mathrm{K}$ ). The calculated $\alpha n$ values were given in Tables 2 and 3.

If an electrode process includes a protonation step, the currents become $\mathrm{pH}$ dependent. The number of protons, $\mathrm{m}_{\mathrm{H}}^{+}$, involved per molecule of IM in the ratedetermining step (RDS) are calculated from the slopes (= $0.059 \mathrm{~m}_{\mathrm{H}}^{+} / \alpha n$ ) of the graph of $E_{\mathrm{p}} v s . \mathrm{pH}$ (Figure 3) and $\alpha n$ values which is determined by means of the halfpeak-width (Tables 2 and 3). The determined proton numbers in the RDS of the electrode reaction are also given in Tables 2 and 3. As can be seen in Table 2, at the RDS of the electrode reaction of the first reduction peak of IM, the values of $\mathrm{m}_{\mathrm{H}}^{+}$calculated lie in the range of<smiles>N/N=C1\C(=O)Nc2ccccc21</smiles>

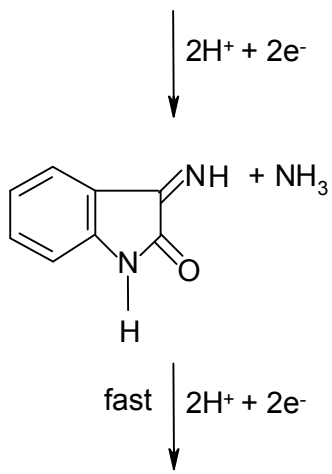<smiles>NC1C(=O)Nc2ccccc21</smiles>

Scheme 4. Tentative reduction mechanism for peak I (in the $\mathrm{pH}$ range $2-8$ ).

1.55-1.69, indicating that two protons are consumed. In addition, for the peak II, the values of $m_{\mathrm{H}^{+}}$calculated lie in the range of $1.90-2.00$, showing the involvement of two protons in the RDS in the $\mathrm{pH}$ range 6.00-9.00 (Table 3). The data presented in Table 2 are also different from the results of IM at RDS on glassy carbon electrode. ${ }^{21}$

Table 2. The square-wave voltammetric data obtained for peak I

\begin{tabular}{ccccccc}
\hline $\mathrm{pH}$ & $W_{1 / 2} / \mathrm{mV}$ & $\alpha n$ & $\alpha(n=1)$ & $\alpha(n=2)$ & $\left(\partial E_{\mathrm{p}} / \partial \mathrm{pH}\right) / \mathrm{mV}$ & $m_{\mathrm{H}^{+}}$ \\
\hline 2 & 55.22 & 1.64 & $1.64^{(\mathrm{a})}$ & 0.82 & 60.7 & 1.69 \\
4 & 56.73 & 1.59 & $1.59^{(\mathrm{a})}$ & 0.80 & 60.7 & 1.64 \\
6 & 53.57 & 1.69 & $1.69^{(\mathrm{a})}$ & 0.85 & 60.7 & 1.74 \\
8 & 60.00 & 1.51 & $1.51^{(\mathrm{a})}$ & 0.76 & 60.7 & 1.55 \\
9 & 69.56 & 1.30 & $1.30^{(\mathrm{a})}$ & 0.65 & 128.6 & $2.83^{(\mathrm{a})}$ \\
\hline
\end{tabular}

(a) Highly values

Table 3. The square-wave voltammetric data obtained for peak II

\begin{tabular}{ccccccc}
\hline $\mathrm{pH}$ & $W_{1 / 2} / \mathrm{mV}$ & $\alpha n$ & $\alpha(n=1)$ & $\alpha(n=2)$ & $\left(\partial E_{\mathrm{p}} / \partial \mathrm{pH}\right) / \mathrm{mV}$ & $m_{\mathrm{H}^{+}}$ \\
\hline 6 & 69.09 & 1.31 & $1.31^{\text {(a) }}$ & 0.66 & 90.4 & 2.00 \\
8 & 70.00 & 1.29 & $1.29^{\text {(a) }}$ & 0.65 & 90.4 & 1.98 \\
9 & 72.73 & 1.24 & $1.24^{(\mathrm{a})}$ & 0.62 & 90.4 & 1.90 \\
\hline
\end{tabular}

(a) Highly values 


\section{Electrode Reaction Mechanism}

From the data given in Tables 2 and 3, it is obvious that the RDSs of peaks I and II of IM involve two electrons and two protons. So, the mechanism of the reduction process for peak I of IM in the $\mathrm{pH}$ range of $2-8$ can be suggested as given in Scheme 4:

As can be seen in Scheme 4, the ( $=\mathrm{N}-\mathrm{NH}-)$ single bond of IM was cleaved with the uptake of two electrons and two protons. ${ }^{60,61}$ And then the intermediate product of the electrode process was rapidly reduced to the amine by means of 2-electron process. As a result, both reduction processes occur at same potential. ${ }^{62-64}$

On the other hand, the reduction mechanism of peak II in the $\mathrm{pH}$ range of 6-9 may be written as seen in Scheme 5:

It is well known that the reduction process of azo compounds in neutral and basic media takes place via $2 \mathrm{e}^{-} / 2 \mathrm{H}^{+} .{ }^{65}$ On the basis of above results, the second reduction process of IM can be sourced from the consumption of $2 \mathrm{e}^{-}$and $2 \mathrm{H}^{+}$for the reduction of $-\mathrm{N}=\mathrm{N}-$ group on the tautomeric form of IM (Scheme 5).

\section{CONCLUSIONS}

In this paper, a detailed electrochemical study of IM at HMDE was carried out over a large $\mathrm{pH}$ range. From the aforementioned experimental results and discussions, we can obtain the below conclusions:

1. The reduction process of IM is irreversible character.

2. The electrode reaction of IM is $\mathrm{pH}$ dependent.

3. The peak currents of IM are generally diffusioncontrolled with slightly contribution of adsorption.

4. The first electrode reaction of IM in the $\mathrm{pH}$ range from 2 to 8 occurred with consumption of $2 \mathrm{e}^{-} / 2 \mathrm{H}^{+}$. Also, the second electrode process of IM includes the transfer of two electrons and two protons in the $\mathrm{pH}$ range of $6-9$.

5. $\mathrm{p} K_{\mathrm{a}}$ value of IM has been determined to be about 7.41 .

\section{REFERENCES}

1. J. F. M. Da Silva, S. J. Garden, and A. C. Pinto, J. Brazil. Chem. Soc. 12 (2001) 273-324.

2. B. C. Radovanović and S. S. Konstantinović, Hemijska Industrija 57 (2003) 444-448.

3. V. Alagarsamy, R. Revathi, S. Meena, K. V. Ramaseshu, S. Rajasekaran, and E. De-Clerco, Indian J. Pharm. Sci. 66 (2004) $459-462$.

4. R. S. Varma and W. L. Nobles, J. Pharm. Sci. 64 (1975) 881882 .

5. Y. Teitz, D. Ronen, A. Vansover, T. Stematsky, and J. L. Rigg, Antivir. Res. 24 (1994) 305-314.

6. A. Gürsoy, N. Karali, S. Büyüktimkin, Ş. Demirayak, A. C. Ek- inci, and H. Özer, Farmaco 51 (1996) 437-442.

7. S. N. Pandeya, A. S. Raja, and J. P. Stables, J. Pharm. Pharmaceut. Sci. 5 (2002) 266-271.

8. S. N. Pandeya, S. Smitha, M. Jyoti, and S. K. Sridhar, Acta Pharm. 55 (2005) 27-46.

9. B. Murukan and K. Mohanan, Transit. Metal Chem. 31 (2006) $441-446$.

10. D. I. Dochinets, V. V. Petrenko, and B. P. Zorya, Zh. Anat. Khim. 44 (1989) 510-513.

11. C. M. Armstrong, P. V. Bernhardt, P. Chin, and D. R. Richardson, Eur. J. Inorg. Chem. 6 (2003) 1145-1156.

12. J. -L. Schmitt, A. -M. Stadler, N. Kyritsakas, and J. -M. Lehn, Helv. Chim. Acta 86 (2003) 1598-1624.

13. L. M. Hayden, W. -K. Kim, A. P. Chafin, and G. A. Lindsay, J. Polym. Sci. Part B: Pol. Phys. 39 (2001) 895-900.

14. M. Bakir, I. Hassan, T. Johnson, O. Brown, O. Green, C. Gyles, and M. D. Coley, J. Mol. Struct. 688 (2004) 213-222.

15. G. Farnia, G. Capobianco, and A. Romanin, J. Electroanal. Chem. Interfacial Electrochem. 45 (1973) 397-404.

16. F. A. Rashwan, Am. J. Appl. Sci. 2 (2005) 1153-1157.

17. M. P. Sathisha, V. K. Revankar, and K. S. R. Pai, Metal-Based Drugs 2008 (2008) 1-11.

18. A. K. Gupta and R. S. J. Sindal, J. Chem. Sci. 121 (2009) 347-351.

19. C. Karaaslan and S. Suzen, Int. J. Electrochem. 2011 (2011) 10 pages, Article ID 154804.

20. V. C. Diculescu, S. Kumbhat, and A. M., Oliveira-Brett, Anal. Chim. Acta 575 (2006) 190-197.

21. S. C. B. Olivera, I. P. G. Fernandes, B. V. Silva, and A. C. Pinto, J. Electroanal. Chem. 689 (2013) 207-215.

22. S. Çakır and E. Biçer, Russian J. Electrochem. 47 (2011) 805 810 .

23. S. Çakır and E. Biçer, J. Iran. Chem. Soc. 7 (2010) 394-404.

24. S. Çakır and E. Biçer, J. Chil. Chem. Soc. 55 (2010) 236-239.

25. T. A. Enache and A. M. Oliveira-Brett, Electroanalysis 23 (2011) 1337-1344.

26. E. A. Hillard, F. C. de Abreu, D. C. Ferreira, G. Jaouen, M. O. Goulart, and C. Amatore, Chem. Commun. 23 (2008) 26122628.

27. G. Dryhurst, Electrochemistry of Biological Molecules, Academic Press, Inc., New York, 1977.

28. A. Masek, E. Chrzescijanska, and M. Zaborski, Int. J. Electrochem. Sci., 9 (2014) 7904-7915.

29. B. S. Sherigara, Y. Shivaraj, R. J. Mascarenhas, S. Rainoji, and B. Kalluraya, Croat. Chem. Acta 79 (2006) 273-279.

30. H. M. Fahmy and M. H. Elnagdi, Electrochim. Acta 23 (1978) 255-260.

31. N. Raju and A. Ramachandraiah, E-Journal of Chemistry, 7 (2010) 583-592.

32. A. Ryan, N. Laurieri, I. Westwood, C. -J. Wang, E. Lowe, and E. Sim, Journal of Molecular Biology 400 (2010) 24-37.

33. R. J. Abdel-Jalil, E. Q. El Momani, M. Hamad, W. Voelter, M. S. Mubarak, B. H. Smith, and D. G. Peters, Monatshefte fur Chemie 141 (2010) 251-258.

34. H. Shirinzadeh, A. D. Yılmaz, M. Gümüştaş, S. Süzen, S. Özden, and S. A. Özkan, Combinatorial Chemistry and High Throughput Screening 13 (2010) 619-627.

35. G. Visbal, G. San-Blas, A. Maldonado, Á. Álvarez-Aular, M. V. Capparelli, and J. Murgich, Steroids 76 (2011) 1069-1081.

36. R. Jain, V. K. Arya, S. Karaiya, and R. Yadav, Journal of Scientific and Industrial Research 72 (2013) 160-165.

37. S. Çakır, E. Biçer, M. Odabaşoğlu, and Ç. Albayrak, J. Braz. Chem. Soc. 16 (2005) 711-717.

38. E. Biçer and C. Arat, Croat. Chem. Acta 82 (2009) 583-593.

39. O. Çakır and E. Biçer, Portugalice Electrochim. Acta 16 (1998) 11-23.

40. M. E. Cardinali, I. Carelli, and A. Trazza, J. Electroanalyt. Chem. Interfacial Electrochem. 34 (1972) 543-546. 
41. H. R. Thirsk (Senior Reporter), Electrochemistry (A spealist periodical report), vol. 4, The Chemical Society Burlington House, London, 1974, p. 300.

42. S. Rollas and S. G. Küçükgüzel, Molecules 12 (2007) 1910-1939.

43. B. Murukan and K. Mohanan, J. Enzym. Inhib. Med. Chem. 22 (2007) 65-70.

44. R. F. Radman, A. M. Ismail, and N. A. Al-Jallal, Journal of Saudi Chemical Society 14 (2010) 223-229.

45. http://www.chemicalland21.com/industrialchem/inorganic/HYD RAZINE\%20HYDRATE.htm (Accessed in June 15, 2014)

46. A. D. Kulkarni, S. A. Patil, and P. S. Badami, Int. J. Electrochem. Sci. 4 (2009) 717-729.

47. P. Zuman and C. L. Perrin, Organic Polarography; Interscience publishers a division of John Wiley\&Sons, New York, 1969.

48. E. Iannone, Labs on Chip: Principles, Design and Technology, CRC Press, New York, 2015, Chapter 1, p. 46.

49. A. E. Harvey and D. L. Manning, J. Am. Chem. Soc. 72 (1950) 4488-4493.

50. D. Y. Chung and E. H. Lee, J. Ind. Eng. Chem. 12 (2006) 962-966.

51. P. Anand, A. B. Kunnumakkara, R. A. Newman, and B. B. Aggarwal, Mol. Pharm. 4 (2007) 807-818.

52. I. Ya. Bershtein and O. F. Ginzburg, Russ. Chem. Rev. 41 (1972) 97-110.

53. J. Reijenga, A. van Hoof, A. van Loon, and B. Teunissen, Analytical Chemistry Insights 8 (2013) 53-71.
54. A. M. Beltagi, M. M. Ghoneim, and A. Radi, J. Pharmaceut. Biomed. 27 (2002) 795-801.

55. R. S. Nicholson and I. Shain, Anal. Chem. 36 (1964) 706-723.

56. A. J. Bard and L. R. Faulkner, Electrochemical Methods: Fundamentals and Applications, Wiley, New York, 1980.

57. F. Man and S. Omanović, J. Electroanal. Chem. 568 (2004) 301313.

58. P. Mericam, M. Astruc, and X. Andrieu, J. Electroanal. Chem. 169 (1984) 207-220.

59. I. Ali and S. Omanović, Int. J. Electrochem. Sci. 8 (2013) 42834304.

60. T. M. Florence, D. A. Johnson, and G. E. Batley, J. Electroanal. Chem. 50 (1974) 113-127.

61. T. M. Florence, J. Electroanal. Chem. 52 (1974) 115-132.

62. S. Patai, The Chemistry of the Hydrazo, Azo and Azoxy Groups, Part I, John Wiley\&Sons, Interscience Publications, London, 1975.

63. P. Zuman, Topics in Organic Polarography, Plenum Press, New York, 1970.

64. M. R. D. Reddy, A. R. G. Prasad, Y. N. Spoorthy, and L. R. K. R. Ravindranath, Anal. Bioanal. Electrochem. 5 (2013) 740-763.

65. Swati, P. Singh, R. Karnawat, I. K. Sharma, and P. S. Verma, International Journal of Chem Tech Research 3 (2011) 11641171. 